\title{
Augalų maisto medžiagų (N, P, K) nuo kalvų šlaitų praradimas su dirvožemiu ir vandeniu
}

Irena Kinderienè,

Gintaras Jarašiūnas,

Danutė Karčauskienė

Lietuvos agrariniu ir mišku mokslu centro Véžaičių filialas, Gargždu g. 29, LT-96216 Véžaičiai, Klaipèdos r. El.paštas:kaltbs@kaltbs.lzi.lt
Eksperimentai daryti 2011-2012 m. Lietuvos agrarinių ir miškų mokslų centro (LAMMC) Věžaičių filialo trijuose Kaltinènų dirvožemio erozijos stacionarų laukuose, esančiuose $7-9^{\circ}, 9-11^{\circ}$ ir $7-8^{\circ}$ statumo šlaituose. Dirvožemis - menkai ir vidutiniškai eroduotas, giliau glèjiškas, pasotintasis balkšvažemis - Jlg4-b-el ir Jlg4-b-e2 (Endohypogleyic-Eutri Albeluvisol - Abe-gld-el ir Abe-gld-e2). Kiekviename stacionaro šlaite yra po 10 laukelių. Tyrimo metais stacionaruose augintos daugiametès žolès, vasariniai miežiai, bulvès, laikytas juodasis pūdymas ir ilgaamžiai šienaujami bei nešienaujami žolynai.

Nustatyta, kad vandeninès dirvožemio erozijos nuostoliai, vandens nuotèkis ir prarastų maisto medžiagų kiekis labiausiai priklausè nuo šlaito dirvožemio apželdinimo augalais ir granuliometrinès dirvožemio sudèties. Šlaitai, apauginti ilgalaikiais žolynais, kuriuose susiformavusi stipri velèna, atsparūs ardymui. Kai dirvožemis be augalų, pūdymuoja, dirvožemio nuostoliai didžiausi lengvo priemolio $9-11^{\circ}$ šlaite $\left(229,34 \mathrm{t} \mathrm{ha}^{-1}\right)$, o vandens nuotekis - vidutinio ir sunkaus priemolio šlaituose. Mažiausias vandens nuotèkis $\left(308,3-843,6 \mathrm{hl} \mathrm{ha}^{-1}\right)$ ir minimalūs sauso dirvožemio nuostoliai $\left(0-1,56 \mathrm{t} \mathrm{ha}^{-1}\right)$ nustatyti $9-11^{\circ}$ lengvo priemolio šlaite, apželdintame ilgalaikiais daugiakomponenčiais žolynais. Esant juodajam pūdymui arba dirvožemiui be augalinès dangos, jautriausias nuardymui ir N, P, K maisto medžiagų netekimui buvo lengvo priemolio statesnio $\left(9-11^{\circ}\right)$ šlaito dirvožemis: per dvejus metus su dirvožemiu ir vandens nuotèkiu judriojo fosforo prarasta $34,39 \mathrm{~kg} \mathrm{ha}^{-1}$, azoto $-12,16 \mathrm{~kg} \mathrm{ha}^{-1}$, judriojo kalio - 32,86 $\mathrm{kg} \mathrm{ha}^{-1}$.

Tyrimais nustatyta, jog tarp paviršinio vandens nuotèkio ir mènesio krituliu kiekio buvo vidutinè priklausomybė $\left(r=0,61^{\star}-0,69^{\star}\left(2011 \mathrm{~m}\right.\right.$.), $r=0,54-0,64^{\star}$ $(2012 \mathrm{~m}$.)). Dirvožemio nuostoliai kalvų šlaituose mažai priklausẻ nuo mènesio kritulių kiekio.

Raktažodžiai: šlaitai, erozija, dirvožemio nuostoliai, nuotèkis, N, P, K, sëjomainos, stacionarai

\section{IVADAS}

Vandens nuotèkis nuo kalvos šlaitų ir dirvožemio erozija mažina žemès našumą, augalų produktyvumą (Brunner et al., 2008), skatina aplinkosaugines, ribojančias žemès ūkio veiklą, problemas (Moreno-de las Heras et al., 2010). Šiaurès Europos šalyse suprasta, kad dirvožemio erozijos problema susijusi ne su faktiniu dirvožemio praradimu, bet su neigiamu poveikiu dirvožemio kokybei netenkant augalams reikalingiausių maisto medžiagų (Kirkby, 2006). Suomijos tyrèjai nustate, kad dèl žemdirbystès šalyje ị vandens telkinius patenka $62 \% \mathrm{P}$ ir $51 \% \mathrm{~N}$ (Warsta, 2011). J. Vaitiekūnienè (2006), ištyrusi 130 Lietuvos upių vandens kokybę, nustatè, kad $72 \%$ fosforo ir $98 \%$ nitratų kiekio ị upes patenka dèl žemès ūkio taršos. JAV mokslininkų duomenimis, ịvairias žoles smèlio dirvožemyje patręšus granuliuotomis $\mathrm{P}$ trąšomis 61 ir $105 \mathrm{~kg} \mathrm{ha}^{-1}$, po 45 mèn. fosforo išplovimo nuostoliai sudare net 22,9 ir $37,8 \mathrm{~kg} \mathrm{ha}^{-1}$ (Erickson et al., 2005). Kiti 
tyrèjai pateikia duomenų, jog intensyvios žemès ùkio gamybos ūkiuose 50-70 \% maisto medžiagu yra nepanaudojamos augalų ir yra nuplaunamos paviršiumi ar išplaunamos iš dirvožemio ił gruntinius vandenis (Asghari et al., 2011).

Tręšiant augalus norima užtikrinti jų produktyvumą, stengiamasi $\mathfrak{i}$ dirvą grąžinti didesnius maisto medžiagų kiekius negu jų reikia užauginti derlių. Tačiau daug azoto nepageidaujama aplinkosaugos požiūriu (dèl galimų didesnių ịplovimo ir nuplovimo nuostolių). Daugiausia dirvų, turinčių labai mažai ir mažai mineralinio azoto, yra Rytu Lietuvoje - apie 70 \%, o Vakarų ir Vidurio Lietuvoje tokių dirvų yra 40-50 \% (Staugaitis ir kt., 2009).

Dirvožemio eroziją vertinant Europos mastu ivairiose klimato zonose reljefo ir augalinès dangos sąlygomis nustatyta, kad dirvožemio netekimas nuo kalvos šlaitų labiausiai priklauso nuo šlaito polinkio bei auginamų augalų (Cerdan et al.,
2010). Kalvų šlaituose auginant pasèlius netenkamas didesnis viršutinio dirvožemio sluoksnis negu esant natūraliai augmenijai (Maetens et al., 2012). Kalvotame reljefe paviršinio vandens nuotèkis šlaitu yra tiesiogiai susijęs su augalų maisto medžiagų ir pesticidų (Maetens et al., 2012) bei dirvožemio netekimu (Vanmaercke et al., 2011), sukeliančiu potencialaus derliaus nuostolius.

Dirvožemio erozija yra ekologinè problema, nes iš esmès prisideda prie augalu maistiniu medžiagų nuotèkio ì vandenynus, sukeldama paviršinių vandens telkinių eutrofikaciją (Onyando et al., 2005). Dèl vykstančios eutrofikacijos nitratais teršiamos upių ir jūrų ekosistemos (London, 2005).

Tyrimų tikslas - ịvertinti pagrindinių augalų maisto medžiagu $(\mathrm{N}, \mathrm{P}, \mathrm{K})$ netekimą dèl erozijos su dirvožemiu ir paviršiniu vandens nuotèkiu, nustatyti jų kitimo ribas bei priežastis skirtingose žemènaudose.

\section{1 lentelè. Stacionaruose auginti augalai}

Table 1. Plants grown in field experiments (stationaries)

\begin{tabular}{|c|c|c|}
\hline $\begin{array}{l}\text { Laukelių } \\
\text { Nr. } \\
\text { Number } \\
\text { of plots } \\
\end{array}$ & $\begin{array}{l}2011 \mathrm{~m} . \\
2011 \text { year }\end{array}$ & $\begin{array}{l}2012 \mathrm{~m} . \\
2012 \text { year }\end{array}$ \\
\hline 1. & $\begin{array}{l}\text { Dobilų-motiejukų mišinys I n. m. (Dž I) / Clover } \\
\text { and timothy mixture (PG), 1st year of use }\end{array}$ & $\begin{array}{l}\text { Dobilų-motiejukų mišinys II n. m. (Dž II) / Clo- } \\
\text { ver and timothy mixture (PG), 2nd year of use }\end{array}$ \\
\hline 2. & $\begin{array}{c}\text { Šunažolių-raudonųjų eraičinų mišinys III n. m. } \\
\text { (Dž III) / Cocksfoot and fescue mix (PG), 3rd year } \\
\text { of use }\end{array}$ & $\begin{array}{c}\text { Šunažolių-raudonujue eraičinų mišinys IV n. m. } \\
\text { (Dž IV) / Cocksfoot and fescue mix }(P G), \text { th year } \\
\text { of use }\end{array}$ \\
\hline 3. & $\begin{array}{l}\text { Dobilų-motiejukų mišinys I n. m. (Dž I) / Clover } \\
\text { and timothy mixture (PG), 1st year of use }\end{array}$ & $\begin{array}{l}\text { Dobilų-motiejukų mišinys II n. m. (Dž II) / Clo- } \\
\text { ver and timothy mixture (PG), 2nd year of use }\end{array}$ \\
\hline 4. & Vasariniai miežiai (M) / Spring barley $(B)$ & Juodasis pūdymas (Jp) / Black fallow (BF) \\
\hline 5. & $\begin{array}{c}\text { Ilgaamžiai } \begin{array}{c}\text { nenaudojami ir } \\
\text { daugiakomponenčiai žolynai }(\mathrm{NŽ})\end{array} \\
\text { soil formation }(\mathrm{SF})\end{array}$ & $\begin{array}{l}\text { Ilgaamžiai nenaudojami ir netręšiami daugia- } \\
\text { komponenčiai žolynai (NŽ) } \\
\text { Sward for soil formation }(S F)\end{array}$ \\
\hline 6. & 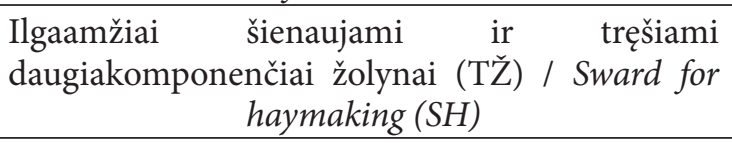 & $\begin{array}{l}\text { Ilgaamžiai šienaujami ir tręšiami daugiakompo- } \\
\text { nenčiai žolynai (TŽ) / Sward for haymaking }(\mathrm{SH})\end{array}$ \\
\hline 7. & Bulvès (B) / Potatoes $(P)$ & Vasariniai miežiai $(\mathrm{M})$ / Spring barley $(B)$ \\
\hline 8. & Vasariniai miežiai (M) / Spring barley $(B)$ & Vasariniai miežiai (M) / Spring barley $(B)$ \\
\hline 9. & $\begin{array}{l}\text { Vasariniai miežiai }+ \text { šunažolių-raudonųjų } \\
\text { eraičinų mišinio issèlis }(\mathrm{M}+\mathrm{dž}) / \text { Spring bar- } \\
\text { ley }+ \text { cocksfoot and fescue mixture undercrop } \\
(B+P G)\end{array}$ & $\begin{array}{c}\text { Šunažolių-raudonųjų eraičinų mišinys I n. m. } \\
\text { (Dž I) / Cocksfoot and fescue mixture (PG), 1st } \\
\text { year of use }\end{array}$ \\
\hline 10. & Bulvès (B) / Potatoes $(P)$ & $\begin{array}{c}\text { Miežiai + dobilų-motiejukų mišinio ìsèlis } \\
(\mathrm{M}+\mathrm{dž}) / \text { Barley }+ \text { clover and timothy mixture un- } \\
\text { dercrop }(B+P G)\end{array}$ \\
\hline
\end{tabular}




\section{EKSPERIMENTŲ VIETA IR DIRVOŽEMIS}

Lauko eksperimentai daryti LAMMC Vėžaičių filiale, Kaltinènų erozijos stacionaruose, įrengtuose $1993 \mathrm{~m} .7-9^{\circ}, 9-11^{\circ}$ ir $7-8^{\circ}$ polinkio šlaituose. Eksperimentų vietovés dirvožemis - menkai ir vidutiniškai eroduotas, giliau glejjiškas, pasotintasis balkšvažemis - Jlg4-b-el ir Jlg4-b-e2 (Endohypogleyic-Eutri Albeluvisol - Abe-gld-el ir Abe-gld-e2) (Jankauskas, Jankauskienè, 2003). Šlaitų viršutinių ir vidurinių dalių dirvožemis vidutiniškai eroduotas, o apatinių - menkai eroduotas. Šlaitų dirvožemiai granuliometrinès sudėties atžvilgiu pagal Fere trikampi yra tokie: dulkiškas vidutinio sunkumo priemolis ant dulkiško lengvo molio $\left(\mathrm{dp}_{1} / \mathrm{dm}\right)-7-9^{\circ}$ šlaitas; dulkiškas lengvas priemolis ant rišlaus smèlio su giliau slūgsančiu dulkišku vidutinio sunkumo priemoliu $\left(\mathrm{dp} / \mathrm{s}_{1} / \mathrm{dp}_{1}\right)-9-11^{\circ}$ šlaitas; dulkiškas sunkus priemolis $\left(\mathrm{dp}_{2} / \mathrm{dp}_{2}\right)-7-8^{\circ}$ polinkio šlaitas.

Daugiakomponenčio žolių sẻklų mišinio sudètyje buvo motiejukai, raudonieji eraičinai, pievinès miglès, baltieji dobilai ir garždeniai. Visų jų ì mišinị imta po $20 \%$ nuo hektarui rekomenduojamos normos.

Nuo pat bandymų i̇rengimo pradžios mineralinėmis trąšomis visais tyrimų metais tręšiama vienodai - javai be issèlio po $\mathrm{N}_{60}, \mathrm{P}_{60}, \mathrm{~K}_{60}$. Miežiams su isèliu N skiriama $45 \mathrm{~kg} \mathrm{ha}^{-1}$. Visos daugiametès žolès trę̌íamos $\mathrm{P}_{60}, \mathrm{~K}_{60}$, o azotu diferencijuotai $-\mathrm{N}_{60-120}$. Dobilų-motiejukų mišinys (D-M) I n. m. azotu netręšiamas, o II n. m. išberiama $\mathrm{N}_{60}$ (vieną kartą). Šunažolių-eraičinų ( $\breve{S}$-E) ir sudètingas žolių mišinys TŽ tręšiamas po I ir II žolių pjūties skiriant kiekvieną kartą po $\mathrm{N}_{60}$. Bulvès tręštos $\mathrm{N}_{90} \mathrm{P}_{90} \mathrm{~K}_{120}$ trąšų normomis. Trą̌sos (amonio salietra, kompleksinès NPK $16: 16: 16$ trąšos) išbarstomos prieš javų sèją, o žolèms - vegetacijos pradžioje. D-M mišinys ir daugiakomponentis žolių mišinys šienautas 2 kartus, o Š-E mišinys -3 kartus.

\section{TYRIMO METODAI}

Tiriamų 10 laukelių kiekviename stacionare surinktas nutekantis vanduo ir nunešamas dirvožemis: dviejų gretimų laukelių apsaugose įrengti $2 \mathrm{~m}$ gylio ir 1,5 m skersmens 5 šuliniai, kuriuose sudèti rezervuarai, skirti surinkti dirvožemị ir vandenị. Iš jų vanduo ir dirvožemis semiamas rankiniu būdu, sveriamas. I biukselius paimti sunešto dirvožemio pavyzdžiai sausų medžiagų nustatymui. Apskaitomojo vandens ir dirvožemio kiekis nustatytas po kiekvieno gausesnio lietaus, sukèlusio vandens nutekẻjimą šlaitu arba prisipildžius rezervuarams.

Sunešto ị rinktuvus dirvožemio ir vandens analizės atliktos Lietuvos agrarinių ir miškų mokslo centro Agrocheminių tyrimų laboratorijoje. Judrusis fosforas $(\mathrm{P})$ ir judrusis kalis $(\mathrm{K})$ nustatytas Egner-Riehm-Domingo metodu (A-L), $\mathrm{N}_{\text {min. }}$ dirvožemyje - $1 \mathrm{M} \mathrm{KCl}$ ekstrakcija, nustatyta spektrofotometriniu metodu. Vandens mèginiuose bendrasis azotas $\left(\mathrm{N}_{\text {sum. }}\right)$ nustatytas Kjeldalio metodu.

Augalų vegetacijos periodo sąlygos apibūdintos G. Selianinovo hidroterminiu koeficientu. Hidroterminis koeficientas nustatytas pagal formulę:

$$
\mathrm{HTK}=\Sigma \mathrm{p} / 0,1 \Sigma \mathrm{t}
$$

čia $\Sigma \mathrm{p}$ - kritulių suma $\mathrm{mm}$ per laikotarpi, kurio temperatūra aukštesnè kaip $10{ }^{\circ} \mathrm{C} ; \Sigma \mathrm{t}-$ to paties periodo aktyvių temperatūrų suma ${ }^{\circ} \mathrm{C}$ (Bukantis, Rimkus, 1997).

Bandymų laukelių pradinis plotis - 4,5 m, apsejjamas plotis - 3,2 m, o apskaitomasis - priklausomai nuo derliaus nuemimo technikos užgriebio pločio: javų kombaino - 2,3 m, žolių pjaunamosios - 1,4 m. Laukeliai tęsiasi nuo šlaito viršutinès dalies iki apatinio šlaito trečdalio, kur ịrengti vandens ir dirvožemio rinktuvai. Apskaitomojo laukelio ilgis šlaituose: $7-9^{\circ}-60 \mathrm{~m}, 9-11^{\circ}-65 \mathrm{~m}$ ir 7-8 $8^{\circ}-50 \mathrm{~m}$. Laukeliai išdèstyti rendomizuotai.

Dvejų metų bandymo duomenų vidurkių paklaidoms skaičiuoti naudota formulè:

$$
s_{x}= \pm \sqrt{\frac{S_{x_{1}}^{2}+s_{x_{2}}^{2}}{n}} ;
$$

čia $s_{x}$ yra vidurkio vidutinè paklaida; $n$ - metu skaičius.

Tyrimo duomenys įvertinti naudojant kompiuterines programas ANOVA, STAT iš paketo SELEKCIJA (Tarakanovas, Raudonius, 2003). Koreliaciniai ryšiai nustatyti taikant tiesinę regresiją.

\section{METEOROLOGINĖS SĄLYGOS}

Tyrimų metais vasario, kovo, balandžio ir gegužès mèn. buvo labai mažai kritulių, kurie neviršijo daugiamečio vidurkio, o dirva buvo nepakankamai 
drègna. $2011 \mathrm{~m}$. birželio mèn. kritulių kiekis buvo taip pat beveik $21 \%$ mažesnis negu daugiametis 50-ties metu vidurkis, o $2012 \mathrm{~m}$. buvo šiek tiek viršytas $-9,7 \%$. Antrojoje birželio pusejje abejais tyrimo metais sulaukta gausesnių kritulių (daugiau nei $20 \mathrm{~mm}$ per parą). Liepos pradžios orai taip pat buvo lietingi. $2011 \mathrm{~m}$. liepos mèn. iškrito 110,5 mm kritulių, o $2012 \mathrm{~m}$. - 116,7 mm, atitinkamai daugiametis vidurkis viršytas $22,9 \%$ ir $29,8 \%$ (1 pav.).

Šlaituose dèl gausių kritulių, ypač 2012 m. liepos pradžioje, augalais neapaugusiame dirvožemyje (Jp) su vandeniu ir dirvožemiu patirti dideli paviršinio dirvos sluoksnio ir maisto medžiagu nuostoliai. $2011 \mathrm{~m}$. rugpjūčio mèn. vyravo lietingi orai ir net 4 dienas iškrito daugiau nei $23 \mathrm{~mm}$ kritulių. Šio mėnesio kritulių vidurkis, palyginti su daugiamečiu (1960-2011m.), viršytas 82 \%. Susidare palankios sąlygos netekti maisto medžiagų. 2012 m. rugpjūčio mèn. iškrito puse tiek kritulių negu tuo pačiu laiku 2011 m. 2012 m. rugpjūčio ir rugsèjo mèn. kritulių kiekiai buvo mažesni negu daugiamečiai 50-ties metų vidurkiai, atitinkamai 8,1 ir 20,9 \%. $2011 \mathrm{~m}$. spalio ir lapkričio mén. negausiai palijo, o gruodi iškrito $150,9 \mathrm{~mm}$ kritulių, tai 2,3 karto daugiau negu daugiametis vidurkis $(65,6 \mathrm{~mm})$ ant silpnai pašalusių dirvų (gruodžio mèn. vidurkis $-0,9^{\circ} \mathrm{C}$ ).

$2012 \mathrm{~m}$. oro temperatūra tiek liepos, tiek rugpjūčio mèn. buvo aukštesnè nei vidutinè daugiametè: liepos mèn. - apie $3{ }^{\circ} \mathrm{C}$, o rugpjūčio mèn. $-0,7-1,4{ }^{\circ} \mathrm{C}$ ( 3 pav.). Kitais laikotarpiais buvo artima jai ir nuo $2011 \mathrm{~m}$. temperatūra labai nesiskyrè. Aktyvios augalų vegetacijos laikotarpiu kiek vėsesni orai buvo $2012 \mathrm{~m}$. birželio mèn.

Hidroterminio koeficiento (HTK) skaičiavimai parodè, jog $2011 \mathrm{~m}$. vegetacijos periodu agrometeorologinès sąlygos buvo optimalaus drègnumo iki liepos mèn., o liepos-rugpjūčio mèn. nustatytas perteklinis drégnumas. $2012 \mathrm{~m}$. perteklinio drègnumo sąlygos po sausringo pavasario prasidèjo birželio pabaigoje ir išliko iki rudens pabaigos (2 pav.).

Kritulių gausumu ir intensyviais lietingais periodais, ypač liepos mèn., pasižymèjo $2012 \mathrm{~m}$. orai. Palyginti su 2011 m., pastarųų metų vandens nuotèkis sudare $54-78 \%$. Per ménesi po dvi ar tris vandens apskaitas atlikta sausị, liepą ir spalí. Ju metu surinkta pusė viso metinio nutekejjusio vandens kiekio. $2011 \mathrm{~m}$. lietingesni periodai su perteklinio drèkinimo sąlygomis buvo rugpjūčio $(\mathrm{HTK}=3,3)$ ir rugsejo mèn. $(\mathrm{HTK}=2,0)$.

\section{REZULTATAI}

Vandens nuotèkis nuo skirtingo statumo ir granuliometrinès sudèties šlaitų buvo mažiausias laukeliuose, apželdintais ilgalaikiais žolynais (NŽ, TŽ), kuriuose susiformavusi stipri velèna (2 lentelè). Besiskiriančiais kritulių kiekiu, jų iškritimo laiku

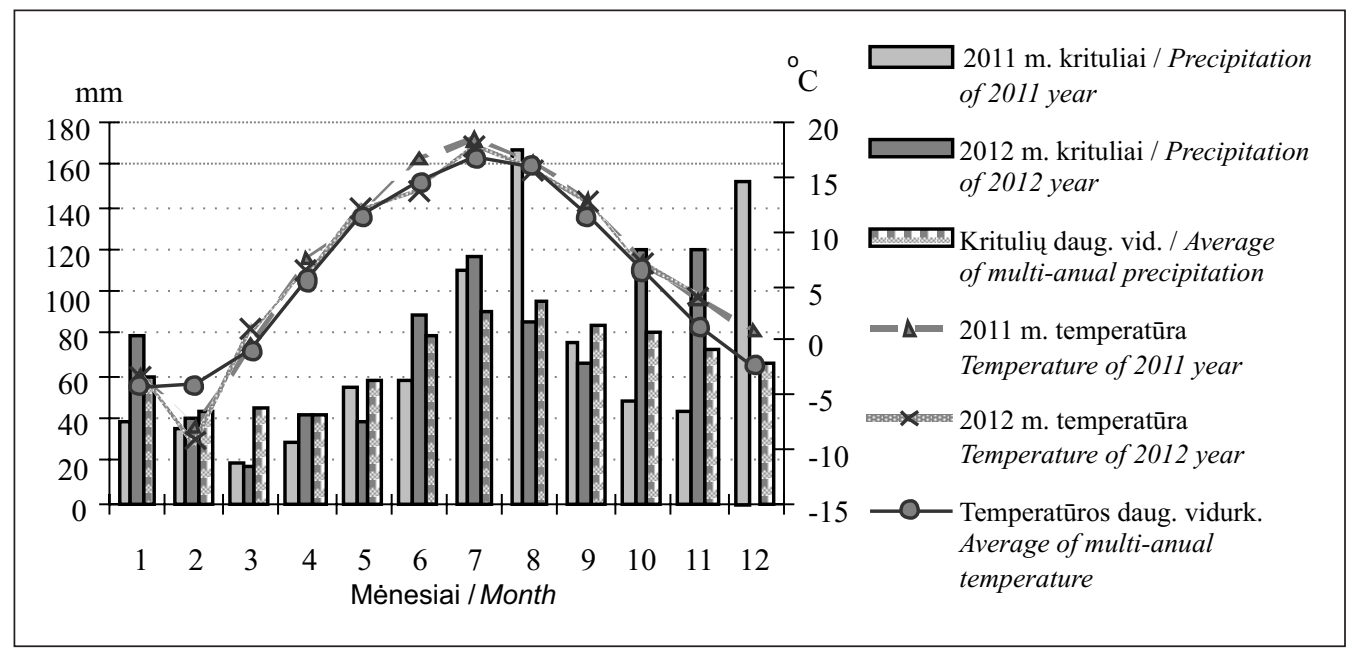

1 pav. Kritulių kiekis ( $\mathrm{mm})$, vidutinè mènesių oro temperatūra $\left({ }^{\circ} \mathrm{C}\right)$ ir daugiamečiai vidurkiai (1960-2011 m.), 2011-2012 m. (Laukuvos MS duomenys)

Fig. 1. The amount of precipitation $(\mathrm{mm})$, average air temperature $\left({ }^{\circ} \mathrm{C}\right)$ and multi-annual averages displayed monthly (Data from the Laukuva Meteorological Station) 


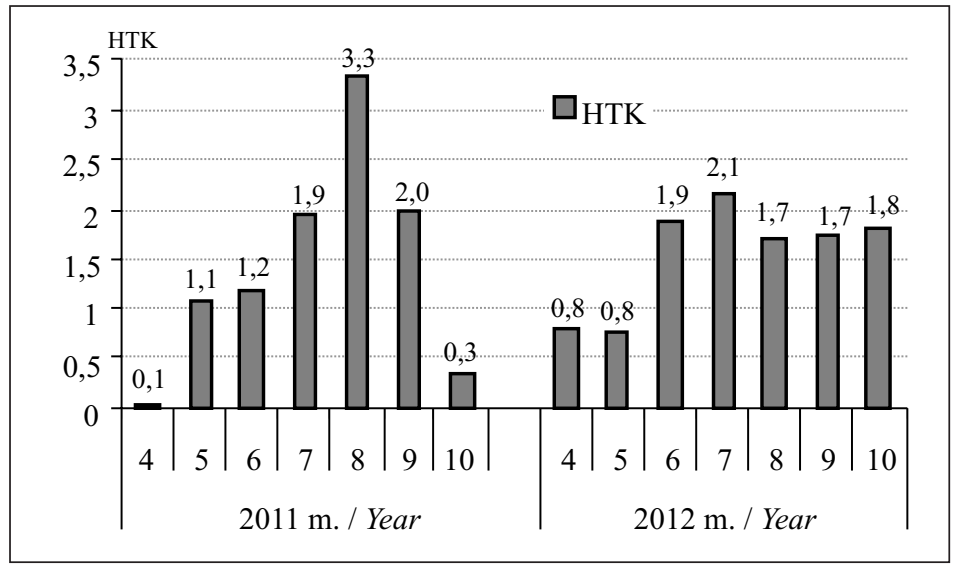

2 pav. Vegetacinio periodo hidroterminis koeficientas

Fig. 2. Hydrothermal coefficient during the growing period

ir intensyvumu, šlaituose su ilgaamžèmis žolėmis vandens nuotèkis tarp atskirų metų beveik nesiskyrè lengvesnio dirvožemio $\left(9-11^{\circ}\right)$ šlaite ir buvo mažiausias, palyginti su kitais šlaitais. Palyginti su $\mathrm{M} / \mathrm{Jp}$, nuo $\mathrm{NŽ}$ apaugusio dirvožemio $7-9^{\circ}, 9-11^{\circ}$ ir $7-8^{\circ}$ šlaituose vandens nuotèkis mažesnis, ati- tinkamai $31,5,75$ ir 50,8 \%, o nuo TŽ, atitinkamai 28,28 ir $63 \%$.

Didesnis vidutinis metinis vandens nuotèkis (916-1 $200 \mathrm{hl} \mathrm{ha}^{-1} \mathrm{~m}^{-1}$ ) tyrimo metu nustatytas nuo vidutinio sunkumo priemolio $\left(7-9^{\circ}\right)$ ir sunkaus priemolio dirvožemio šlaitų $\left(7-8^{\circ}\right)$, apsètų

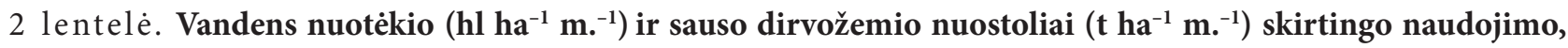
statumo ir dirvožemio granulometrinès sudèties šlaituose 2011-2012 m.

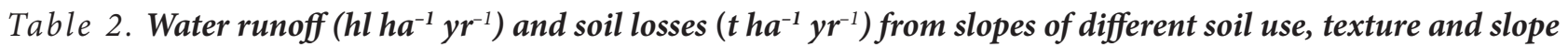
inclination over 2011-2012 years

\begin{tabular}{|c|c|c|c|c|c|c|}
\hline \multirow[b]{2}{*}{$\begin{array}{l}\text { Augalai } \\
\text { Plants }\end{array}$} & \multicolumn{2}{|c|}{$\begin{array}{l}\text { 7-9 } \\
\text { 'slaitas } d p_{1} \\
7-9^{\circ} \text { slope, } d p_{1}\end{array}$} & \multicolumn{2}{|c|}{$\begin{array}{l}9-11^{\circ} \text { slaitas } \mathrm{dp} \\
9-11^{\circ} \text { slope, } d p\end{array}$} & \multicolumn{2}{|c|}{$\begin{array}{l}7-8^{\circ} \text { šlaitas } d p_{2} \\
7-8^{\circ} \text { slope, } d p_{2}\end{array}$} \\
\hline & 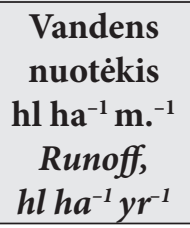 & 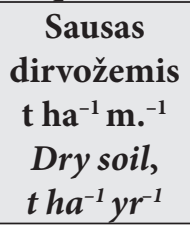 & 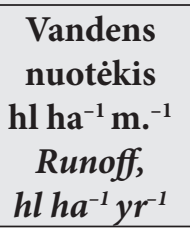 & $\begin{array}{c}\text { Sausas } \\
\text { dirvožemis } \\
\text { t ha }^{-1} \mathrm{~m}^{-1} \\
\text { Dry soil, } \\
\text { tha-1 } y r^{-1}\end{array}$ & 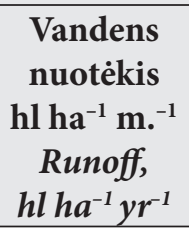 & $\begin{array}{c}\text { Sausas } \\
\text { dirvožemis } \\
\text { t ha }^{-1} \mathrm{~m}^{-1} \\
\text { Dry soil, } \\
\text { t ha }{ }^{-1} \mathrm{yr}^{-1}\end{array}$ \\
\hline $\begin{array}{l}\mathrm{D} \text { ž I/D ž II } \\
P G I / P G I I\end{array}$ & 941,8 & 0,09 & 659,4 & 5,07 & 1153,4 & 0 \\
\hline $\begin{array}{l}\mathrm{D} \text { ž III/D ž IV } \\
P G I I I / P G I V\end{array}$ & 916,2 & 0,02 & 778,4 & 2,51 & 1023,7 & 0 \\
\hline $\begin{array}{c}\text { D } \check{z} \mathrm{I} / \mathrm{D} \check{z} \\
\mathrm{II} / P G I / P G I I\end{array}$ & 1200,7 & 17,41 & 937,3 & 34,95 & 1011,9 & 0,33 \\
\hline $\mathrm{M} / \mathrm{J} \mathrm{p} / B / B F$ & 1173,2 & 16,85 & 1233,4 & 229,35 & 1080,8 & 0,85 \\
\hline NŽ / SF & 803 & 0 & 308,3 & 0,50 & 531,1 & 0 \\
\hline $\mathrm{TŽ} / \mathrm{SH}$ & 843,6 & 1,56 & 456,6 & 0,26 & 514,7 & 0 \\
\hline $\mathrm{B} / \mathrm{M} / \mathrm{P} / \mathrm{B}$ & 937,1 & 0,49 & 857,1 & 3,37 & 980,1 & 0,06 \\
\hline $\mathrm{M} / \mathrm{M} / \mathrm{B} / \mathrm{B}$ & 956,7 & 0,95 & 694,8 & 3,37 & 1136,5 & 0 \\
\hline $\begin{array}{l}\mathrm{M}+\mathrm{dž} / \mathrm{Dž} \mathrm{I} \\
B+P G / P G I\end{array}$ & 1376,3 & 0,01 & 692,3 & 3,65 & 1134,3 & 0,02 \\
\hline $\begin{array}{l}\mathrm{B} / \mathrm{M}+\mathrm{d} z ̌ \\
P / B+P G\end{array}$ & 1221,1 & 0,17 & 703,4 & 3,38 & 1121,6 & 0,26 \\
\hline $\mathrm{R}_{05} / L S D_{05}$ & 331,40 & 11,988 & 533,37 & 114,901 & 233,25 & 0,446 \\
\hline
\end{tabular}


daugiametėmis I-IV m. n. žolèmis (dèl mažesnio laidumo vandeniui ir didesnio molio dalelių kiekio dirvožemyje).

Auginant miežius ir bulves mažesnis kritulių vandens nuotèkis, palyginti su kitais šlaitais, buvo laidesniame vandeniui, $9-11^{\circ}$ lengvo priemolio dirvožemio šlaite tiek atskirais metais, tiek per dvejus metus. Nuo dirvožemio, be augalų (Jp), nutekèjęs vandens kiekis dèl intensyvių $2012 \mathrm{~m}$. liepos liūčių, palyginti su $2011 \mathrm{~m}$. užsèto miežiais nuotèkiu, $7-9^{\circ}, 9-11^{\circ}$ ir $7-8^{\circ}$ šlaituose buvo atitinkamai 3,6, 8,4 ir 2,7 karto didesnis.

Didžiausia per visą tyrimų laikotarpi (2011$2012 \mathrm{~m}$.) sauso dirvožemio netektis - 229,34 $\mathrm{t} \mathrm{ha}^{-1}$ dèl liūtinių vasaros (2012 m. liepa) kritulių nustatyta tik statesniame $9-11^{\circ}$ lengvo priemolio dirvožemio šlaite. $2011 \mathrm{~m}$. nesant liūčių toje pačioje vietoje auginant vasarinius miežius dirvožemio nuostoliai buvo minimalūs - tik $0,01 \mathrm{t} \mathrm{ha}^{-1}$. Minimalūs sauso dirvožemio nuostoliai per dvejus metus, siekiantys $0-0,5 \mathrm{t} \mathrm{ha}^{-1}$ ir $0-1,56 \mathrm{t} \mathrm{ha}^{-1}$, buvo nustatyti ilgaamžiais daugiamečiais žoliniais augalais apaugintuose laukeliuose. Šlaituose su sunkesniu dirvožemiu net ir be augalų Jp laukeliuose nuostoliai 7-9 $9^{\circ}$ šlaite tebuvo tik $16,85 \mathrm{t} \mathrm{ha}^{-1}$, o sunkaus priemolio $7-8^{\circ}$ polinkio šlaite - tik $0,85 \mathrm{t} \mathrm{ha}^{-1} \cdot \mathrm{B} / \mathrm{M}$ ir $\mathrm{M} / \mathrm{M}$ apsètas šlaito dirvožemis augalams vegetuojant buvo atsparus ardymui, o dirvožemio nuostoliai per dvejus metus buvo nedideli $-0-3,37 \mathrm{t} \mathrm{ha}^{-1}$. Panašius vandeninès dirvožemio erozijos rezultatus, priklausiusius nuo kritulių ir dirvos apželdinimo augalais, pateikè ir kiti tyrẻjai (Maetens W. et al., 2012).
Koreliacinè-regresinè ménesio kritulių kiekio ir dirvožemio nuostolių analizè parodè, kad silpnas teigiamas ryšys abejais tyrimų metais buvo tik lengvo ir vidutinio priemolio šlaituose, o tarpusavyje abu požymiai buvo susiję 11,3-15,8 \% (3 lentelè). Sunkaus priemolio nuostoliai šiek tiek priklausė nuo ménesio krituliu $(r=0,12-0,16)$, o požymiai susiję tik 1,2-2,6 \%. Tačiau paviršinio vandens nuotèkis iš esmès priklausẻ nuo kritulių kiekio.

Tiek 2011, tiek $2012 \mathrm{~m} .7^{7}-9^{\circ}$ polinkio šlaite paviršinio vandens nuotèkis 41,4-47,2 \% buvo susijęs su kritulių kiekiu vidutinio stiprumo ryšiu $0,64^{\star}-0,69^{\star}$. Kituose šlaituose tarpusavio koreliaciniai ryšiai silpnesni, tačiau taip pat patikimi.

Didžiausias judriojo fosforo kiekis $34,39 \mathrm{~kg} \mathrm{ha}^{-1}$ - prarastas su nuneštu dirvožemiu nuo $9-11^{\circ}$ statumo lengvo priemolio šlaito (4 lentelè). Šiame šlaite jo nuostoliai $80 \%$ didesni negu $7-9^{\circ}$ šlaite ir $96 \%$ negu $7-8^{\circ}$ šlaite. Mažiausias judriojo fosforo kiekis $\left(0,04-0,47 \mathrm{~kg} \mathrm{ha}^{-1}\right)$ prarastas nuo sunkiausios granuliometrinès sudèties dirvožemị turinčio $7-8^{\circ}$ šlaito, kuriame patirti mažiausi dirvožemio nuostoliai $\left(0-0,85 \mathrm{t} \mathrm{ha}^{-1}\right)$. Apauginant šlaitus tręšiamais žolynais (TŽ) dirvožemio nuostolių dèl vandeninès erozijos nepatirta ir tik nutekejusiame šlaitu vandenyje nustatyti maži prarasto judriojo fosforo kiekiai $\left(0,1-0,11 \mathrm{~kg} \mathrm{ha}^{-1}\right)$. Šiaurès šalyse atlikti tyrimai rodo, kad mažinti fosforo neigiamą poveiki gamtinei aplinkai rekomenduojama pasirenkant sejjomainas su augalais ir nuolat juos auginant dirvoje (Joel et al., 2012).

3 lentelè. Dirvožemio nuostolių $\left(y, \mathbf{k g}^{-1}\right.$ mèn. $\left.{ }^{-1}\right)$ ir vandens paviršinio nuotèkio $\left(y, \mathbf{l}^{-1}\right.$ mèn. $\left.{ }^{-1}\right)$ skirtinguose šlaituose ryšys su kritulių kiekiu $\left(x, \mathrm{~mm}^{-1}\right.$ mèn. $\left.{ }^{-1}\right)$

Table 3. The relationship between the observed soil loss $\left(y, \mathrm{~kg}^{-1}\right.$ month $\left.\mathrm{h}^{-1}\right)$ and surface runoff $\left(y, l^{-1}\right.$ month $\left.^{-1}\right)$ with the amount of precipitation $\left(x, \mathrm{~mm}^{-1} \mathrm{month}^{-1}\right)$ in different slopes

\begin{tabular}{|c|c|c|c|c|c|c|c|}
\hline \multirow{2}{*}{$\begin{array}{l}\text { Šlaitas } \\
\text { Slope }\end{array}$} & \multirow{2}{*}{$\begin{array}{l}\text { Metai } \\
\text { Year }\end{array}$} & \multicolumn{3}{|c|}{$\begin{array}{l}\text { Dirvožemio nuostoliai } \mathrm{kg}^{-1} \mathrm{mèn}^{-1} \\
\text { Sediment loss, } \mathrm{kg}^{-1} \text { month }\end{array}$} & \multicolumn{3}{|c|}{$\begin{array}{l}\text { Vandens nuotèkis } \mathrm{l}^{-1} \text { mèn. }^{-1} \\
\text { Runoff, } l^{-1} \text { month }^{-1}\end{array}$} \\
\hline & & $r$ & $\mathbf{R}^{2}$ & $\begin{array}{c}\text { Regresijos lygtis } \\
\text { Regression equation }\end{array}$ & $r$ & $\mathbf{R}^{2}$ & $\begin{array}{c}\text { Regresijos lygtis } \\
\text { Regression equation }\end{array}$ \\
\hline $7-9^{\circ}$ & 2011 & 0,35 & 0,124 & $y=0,04+0,01 x$ & $0,69^{*}$ & 0,472 & $y=-110,82+9,29 x$ \\
\hline $9-11^{\circ}$ & 2011 & 0,34 & 0,113 & $y=-1,25+0,08 x$ & $0,60^{*}$ & 0,351 & $y=3,11+4,76 x$ \\
\hline $7-8^{\circ}$ & 2011 & 0,12 & 0,012 & $y=0,82+0,01 x$ & $0,61^{*}$ & 0,375 & $y=-42,84+5,85 x$ \\
\hline $7-9^{\circ}$ & 2012 & 0,38 & 0,147 & $y=-133,42+3,40 x$ & $0,64^{*}$ & 0,414 & $y=-16,43+15,32 x$ \\
\hline $9-11^{\circ}$ & 2012 & 0,40 & 0,158 & $y=-1237,85+28,22 x$ & 0,59 & 0,347 & $y=126,60+11,23 x$ \\
\hline $7-8^{\circ}$ & 2012 & 0,16 & 0,026 & $y=0,81+0,04 x$ & 0,54 & 0,288 & $y=121,85+11,57 x$ \\
\hline
\end{tabular}

* $95 \%$ tikimybès lygmuo / * $95 \%$ level of probability 
4 lentelè. Judriojo fosforo $\left(\mathbf{P}_{2} \mathbf{O}_{5}\right)$ nuostoliai su dirvožemiu ir paviršiniu nuotėkiu nuo skirtingo statumo šlaitų (kg ha $\left.{ }^{-1} \mathrm{~m}^{-1}\right)$ 2011-2012 m.

Table 4. Loss of available $\left(\mathrm{P}_{2} \mathrm{O}_{5}\right)\left(\mathrm{kg} \mathrm{ha}^{-1} \mathrm{yr}^{-1}\right)$ with sediment and surface runoff from different slopes during 2011-2012

\begin{tabular}{|c|c|c|c|c|c|c|c|c|c|}
\hline \multirow[b]{2}{*}{$\begin{array}{l}\text { Augalai } \\
\text { Plants }\end{array}$} & \multicolumn{3}{|c|}{$\begin{array}{c}7-9^{\circ} \text { šlaitas } \\
7-9^{\circ} \text { slope }\end{array}$} & \multicolumn{3}{|c|}{$\begin{array}{c}9-11^{\circ} \text { šlaitas } \\
9-11^{\circ} \text { slope }\end{array}$} & \multicolumn{3}{|c|}{$\begin{array}{c}\text { 7-8 }{ }^{\circ} \text { slaitas } \\
7-8^{\circ} \text { slope }\end{array}$} \\
\hline & 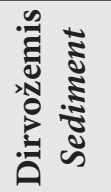 & 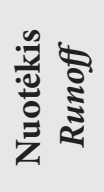 & 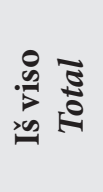 & 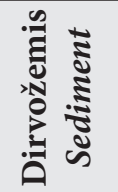 & 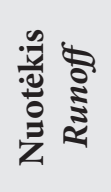 & 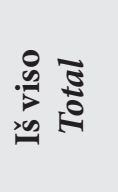 & 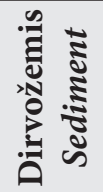 & 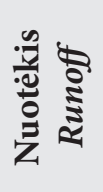 & 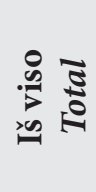 \\
\hline $\begin{array}{l}\mathrm{D} \text { ž I/D ž II } \\
P G ~ I / P G I I\end{array}$ & 0,0 & 0,12 & 0,13 & 3,79 & 0,2 & 3,99 & 0 & 0,04 & 0,04 \\
\hline $\begin{array}{l}\text { D ž III/D ž IV } \\
P G ~ I I I / P G ~ I V\end{array}$ & 0,02 & 0,14 & 0,16 & 0,55 & 0,1 & 0,65 & 0 & 0,1 & 0,1 \\
\hline $\begin{array}{l}\mathrm{D} \text { ž I/D ž II } \\
P G I / P G I I\end{array}$ & 4,64 & 0,1 & 4,74 & 1,51 & 0,05 & 1,56 & 0,12 & 0,2 & 0,14 \\
\hline $\mathrm{M} / \mathrm{J} \mathrm{p} / B / B F$ & 3,37 & 0,1 & 3,47 & 34,39 & 0,23 & 34,62 & 0,22 & 0,25 & 0,47 \\
\hline $\mathrm{NŽ} \mathrm{/} \mathrm{SF}$ & 0 & 0,2 & 0,2 & 1,89 & 0,1 & 1,99 & 0 & 0,1 & 0,1 \\
\hline $\mathrm{TŽ} / \mathrm{SH}$ & 0 & 0,11 & 0,11 & 0 & 0,1 & 0,1 & 0 & 0,1 & 0,1 \\
\hline $\mathrm{B} / \mathrm{M} / \mathrm{P} / \mathrm{B}$ & 0,04 & 0,03 & 0,07 & 0,69 & 0,1 & 0,79 & 0,01 & 0,2 & 0,21 \\
\hline $\mathrm{M} / \mathrm{M} / \mathrm{B} / \mathrm{B}$ & 0,13 & 0,03 & 0,16 & 0,67 & 0,1 & 0,79 & 0 & 0,1 & 0,1 \\
\hline $\begin{array}{l}\mathrm{M}+\mathrm{dž} / \mathrm{Dž} \mathrm{I} \\
B+P G / P G I\end{array}$ & 0,002 & 0,04 & 0,04 & 0,68 & 0,03 & 0,71 & 0,004 & 0,1 & 0,1 \\
\hline $\begin{array}{l}\mathrm{B} / \mathrm{M}+\mathrm{dž} \\
P / B+P G\end{array}$ & 0,03 & 0,1 & 0,13 & 0,56 & 0,01 & 0,57 & 0,07 & 0,4 & 0,47 \\
\hline $\mathrm{R}_{05} / L S D_{05}$ & 2,734 & 0,068 & 1,933 & 17,075 & 0,099 & 12,07 & 0,116 & 0,153 & 0,135 \\
\hline
\end{tabular}

2012 m. juodojo pūdymo laukelyje 9-11 ${ }^{\circ}$ statumo šlaite dèl gausių $(116,7 \mathrm{~mm})$ kritulių prarasta sauso dirvožemio iš esmès daugiau nei kitais augalais apaugusiuose laukeliuose $-229,35 \mathrm{t} \mathrm{ha}^{-1}$. Tai sąlygojo statistiškai esmingus ir didelius judriojo fosforo nuostolius, su prarastu nuo laukelio dirvožemiu, siekiančius net $34,39 \mathrm{~kg} \mathrm{ha}^{-1}$. Su vandens nuotèkiu juodojo pūdymo laukelyje netekta tik $0,23 \mathrm{~kg} \mathrm{ha}^{-1}$ judraus fosforo. Auginant šlaituose bulves ar vasarinius javus judriojo fosforo nuostoliai šiame šlaite buvo $0,79 \mathrm{~kg} \mathrm{ha}^{-1}$, o kituose, sunkesnès granuliometrinès sudèties šlaituose, per dvejus metus jie dar mažesni (dèl apaugusio augalais dirvos paviršiaus). Auginant daugiametes žoles (I-IV n. m.) sunkaus priemolio $7-8^{\circ}$ statumo šlaite judriojo fosforo nuostolių su dirvožemiu ir nutekejjusiu kritulių vandeniu beveik nepatirta. Lengvesnès granuliometrinès sudèties šlaituose, nors ir apaugusiuose augalais, judriojo fosforo nuostoliai buvo iš esmès didesni, atitinkamai 0,13$4,74 \mathrm{~kg} \mathrm{ha}^{-1}$ ir $0,65-3,99 \mathrm{~kg} \mathrm{ha}^{-1}$.

Azoto, kaip ir kitų tirtų maisto medžiagų, nuostoliai su dirvožemiu didžiausi 9-11 ${ }^{\circ}$ lengvos gra- nuliometrinès sudèties dirvožemio šlaite juodojo pūdymo (Jp) laukelyje - 12,16 kg ha ${ }^{-1}$ (5 lentelè). $\mathrm{N}$ nuostoliai su vandens nuotekiu tame pačiame šlaite nuo Jp laukelio buvo 8 kartus mažesni. Ilgalaikiai žolynai apsaugojo dirvožemį nuo ardymo, todèl su dirvožemiu patirti maži mineralinio azoto nuostoliai. Kitų šlaitų daugiamečių žolių I-IV n. m. laukelių paviršiumi su vandens nuotèkiu nuplauti azoto kiekiai didesni negu su prarastu dirvožemiu - 0,56-3,74 $\mathrm{kg} \mathrm{ha}^{-1}$, o nuo vasariniais javais $(M / M)$ apsètų laukelių nuplauta $0,58-4,32 \mathrm{~kg} \mathrm{ha}^{-1}$.

Išskyrus $\mathrm{M} / \mathrm{Jp}$ laukelius, judriojo kalio šlaituose prarasta daugiau su nutekejusiu vandeniu. Auginant šlaituose $\mathrm{B} / \mathrm{M}$ kalio nuostoliai nustatyti taip pat didesni su kritulių vandens nuotèkiu $(0,76-$ 2,3 $\left.\mathrm{kg} \mathrm{ha}^{-1}\right)$ negu su nuneštu dirvožemiu $(0,06-$ $0,83 \mathrm{~kg} \mathrm{ha}^{-1}$ ). Ilgalaikè žolès danga ( $\mathrm{NŽ} \mathrm{ir} \mathrm{TŽ)}$ visiškai apsaugojo dirvožemi nuo erozijos, tačiau dèl žolynų (TŽ) kasmetinio tręšimo mineralinèmis trąšomis nutekejjusiame šlaitu kritulių vandenyje nustatyti 1,2-1,7 karto didesni judriojo kalio nuostoliai negu netręštuose NŽ (6 lentelè). 
5 lentelè. $\mathbf{N}$ nuostoliai su dirvožemiu ir paviršiniu nuotẻkiu nuo skirtingo statumo šlaitų $\left(\mathrm{kg} \mathrm{ha}^{-1} \mathbf{m} \cdot{ }^{-1}\right)$ 2011-2012 m.

Table 5. Loss of $\mathrm{N}\left(\mathrm{kg} \mathrm{ha}^{-1} \mathrm{yr}^{-1}\right)$ with sediment and surface runoff from different slopes during 2011-2012

\begin{tabular}{|c|c|c|c|c|c|c|c|c|c|}
\hline \multirow[b]{2}{*}{$\begin{array}{c}\text { Augalai } \\
\text { Plants }\end{array}$} & \multicolumn{3}{|c|}{$\begin{array}{c}7-9^{\circ} \text { šlaitas } \\
7-9^{\circ} \text { slope }\end{array}$} & \multicolumn{3}{|c|}{$\begin{array}{c}9-11^{\circ} \text { šlaitas } \\
9-11^{\circ} \text { slope }\end{array}$} & \multicolumn{3}{|c|}{$\begin{array}{c}7-8^{\circ} \text { šlaitas } \\
7-8^{\circ} \text { slope }\end{array}$} \\
\hline & 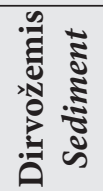 & 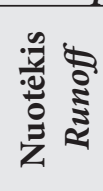 & 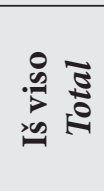 & 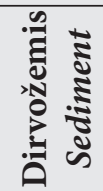 & 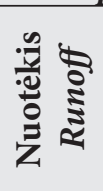 & 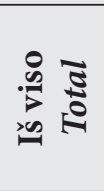 & 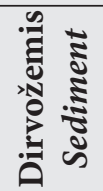 & 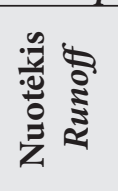 & 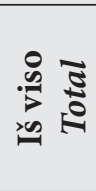 \\
\hline $\begin{array}{l}\mathrm{D} \text { ž I/D ž II } \\
P G I . / P G \text { II }\end{array}$ & 0,001 & 0,56 & 0,56 & 0,001 & 2,80 & 2,80 & 0 & 3,74 & 3,74 \\
\hline $\begin{array}{l}\mathrm{D} \text { ž III/D ž IV } \\
P G I I I / P G I V\end{array}$ & 0 & 1,63 & 1,63 & 0,001 & 2,80 & 2,80 & 0 & 2,40 & 2,4 \\
\hline $\begin{array}{l}\mathrm{D} \text { ž I/D ž II } \\
P G I / P G I I\end{array}$ & 0,86 & 2,30 & 3,16 & 0,001 & 1,80 & 1,80 & 0 & 1,7 & 1,7 \\
\hline $\mathrm{M} / \mathrm{J} \mathrm{p} / B / B F$ & 0,50 & 2,64 & 3,14 & 12,16 & 1,50 & 13,66 & 0,04 & 1,76 & 1,8 \\
\hline $\mathrm{NŽ} \mathrm{/} \mathrm{SF}$ & 0 & 2,75 & 2,75 & 0,02 & 0,74 & 0,76 & 0 & 1,86 & 1,86 \\
\hline TŽ / SH & 0 & 1,99 & 1,99 & 0,001 & 0,92 & 0,92 & 0 & 3,11 & 3,11 \\
\hline $\mathrm{B} / \mathrm{M} / \mathrm{P} / \mathrm{B}$ & 0,004 & 0,87 & 0,87 & 0,04 & 0,26 & 0,30 & 0,002 & 2,25 & 2,25 \\
\hline $\mathrm{M} / \mathrm{M} / \mathrm{B} / \mathrm{B}$ & 0,014 & 0,58 & 0,59 & 0,183 & 0,86 & 1,04 & 0 & 4,32 & 4,32 \\
\hline 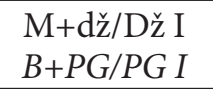 & 0 & 0,73 & 0,73 & 0,072 & 1,10 & 1,17 & 0 & 3,42 & 3,42 \\
\hline $\begin{array}{l}\mathrm{B} / \mathrm{M}+\mathrm{dž} \\
P / B+P G\end{array}$ & 0,005 & 1,53 & 1,53 & 0,027 & 0,52 & 0,55 & 0,005 & 5,03 & 5,03 \\
\hline $\mathrm{R}_{05} / L S D_{05}$ & 0,472 & 1,267 & 0,956 & 6,142 & 1,838 & 4,533 & 0,08 & 1,906 & 1,349 \\
\hline
\end{tabular}

6 lentelè. Judriojo kalio $\left(\mathrm{K}_{2} \mathbf{O}\right)$ nuostoliai su dirvožemiu ir paviršiniu nuotèkiu nuo skirtingo statumo šlaitu $\left(\mathrm{kg} \mathrm{ha}^{-1} \mathrm{~m}^{-1}\right)$ 2011-2012 m.

Table 6. Loss of available $\mathrm{K}_{2} \mathrm{O}\left(\mathrm{kg} \mathrm{ha}^{-1} \mathrm{yr}^{-1}\right)$ with sediment and surface runoff from different slopes during 2011-2012

\begin{tabular}{|c|c|c|c|c|c|c|c|c|c|}
\hline \multirow[b]{2}{*}{$\begin{array}{c}\text { Augalai } \\
\text { Plants }\end{array}$} & \multicolumn{3}{|c|}{$\begin{array}{l}7-9^{\circ} \text { šlaitas } \\
7-9^{\circ} \text { slope }\end{array}$} & \multicolumn{3}{|c|}{$\begin{array}{c}9-11^{\circ} \text { šlaitas } \\
9-11^{\circ} \text { slope }\end{array}$} & \multicolumn{3}{|c|}{$\begin{array}{c}7-8^{\circ} \text { šlaitas } \\
7-8^{\circ} \text { slope }\end{array}$} \\
\hline & 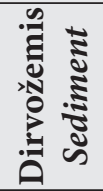 & 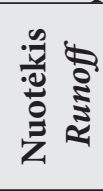 & 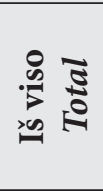 & 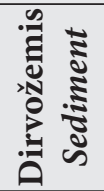 & 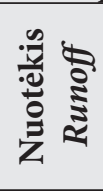 & 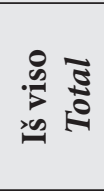 & 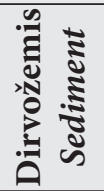 & 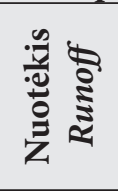 & 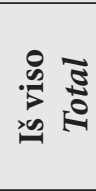 \\
\hline $\begin{array}{l}\mathrm{D} \text { ž I/D ž II } \\
P G I . / P G ~ I I\end{array}$ & 0,02 & 1,35 & 1,37 & 1,38 & 1,7 & 3,08 & 0 & 2,89 & 2,89 \\
\hline $\begin{array}{l}\mathrm{D} \text { ž III/D ž IV } \\
P G I I I / P G I V\end{array}$ & 0,002 & 1,56 & 1,56 & 0,44 & 1,14 & 1,58 & 0 & 3,22 & 3,22 \\
\hline $\begin{array}{l}\mathrm{D} \text { ž I/D ž II } \\
P G ~ I / P G ~ I I\end{array}$ & 5,3 & 2,62 & 7,92 & 1,72 & 2,3 & 4,02 & 0,14 & 3,01 & 3,15 \\
\hline $\mathrm{M} / \mathrm{J} \mathrm{p} / B / B F$ & 3,29 & 2,44 & 5,73 & 32,86 & 1,8 & 34,66 & 0,22 & 1,58 & 1,80 \\
\hline $\mathrm{NŽ} \mathrm{/} \mathrm{SF}$ & 0 & 1,68 & 1,68 & 4,15 & 1,1 & 5,25 & 0 & 2,26 & 2,26 \\
\hline TŽ / SH & 0 & 2,82 & 2,82 & 0 & 1,53 & 1,53 & 0 & 3,11 & 3,11 \\
\hline $\mathrm{B} / \mathrm{M} / \mathrm{P} / \mathrm{B}$ & 0,06 & 0,76 & 0,82 & 0,83 & 1,32 & 2,15 & 0,02 & 1,39 & 1,41 \\
\hline $\mathrm{M} / \mathrm{M} / \mathrm{B} / \mathrm{B}$ & 0,24 & 1,03 & 1,27 & 0,95 & 1,44 & 2,39 & 0 & 2,53 & 2,53 \\
\hline $\begin{array}{l}\mathrm{M}+\mathrm{dž} / \mathrm{Dž} \mathrm{I} \\
B+P G / P G I\end{array}$ & 0,003 & 1,03 & 1,03 & 0,67 & 0,92 & 1,59 & 0,01 & 3,1 & 3,11 \\
\hline $\begin{array}{l}\mathrm{B} / \mathrm{M}+\mathrm{dž} \\
P / B+P G\end{array}$ & 0,09 & 1,38 & 1,47 & 0,80 & 1,3 & 2,1 & 0,18 & 2,36 & 2,54 \\
\hline $\mathrm{R}_{05} / L S D_{05}$ & 0,472 & 0,665 & 0,576 & 6,142 & 0,859 & 4,385 & 0,08 & 0,901 & 0,639 \\
\hline
\end{tabular}


Tik lengvo priemolio 9-11 ${ }^{\circ}$ šlaite, apželdintame ilgalaikiais daugiakomponenčiais netręštais žolynais (NŽ), prarasto su dirvožemiu judriojo kalio nuostoliai $\left(4,15 \mathrm{~kg} \mathrm{ha}^{-1}\right)$ buvo didesni negu auginant kitus augalus, tačiau $87 \%$ mažesni, palyginti su $\mathrm{M} / \mathrm{Jp}$ laukeliu. Prarastas $\mathrm{K}_{2} \mathrm{O}$ su dirvožemiu buvo didžiausias $\mathrm{M} / \mathrm{Jp}$ laukelyje - 32,86 $\mathrm{kg} \mathrm{ha}^{-1}$. Sunkesnès granuliometrinès sudèties ir mažesnio statumo šlaituose juodojo pūdymo laukeliuose dèl mažesnių dirvožemio nuostoliu judriojo kalio prarasta kur kas mažiau: $7-9^{\circ}-3,29 \mathrm{~kg} \mathrm{ha}^{-1}$, o $7-8^{\circ}-0,22 \mathrm{~kg} \mathrm{ha}^{-1}$.

Tyrimo duomenys trijuose stacionariu eksperimentų šlaituose parodé, kad pagrindinių augalų maisto medžiagų netekimas dèl vandeninès dirvožemio erozijos be augalijos, kaip svarbiausio antierozinio veiksnio, labai glaudžiai siejasi su granuliometrine dirvožemio sudètimi ir šlaito polinkiu. Tokius pastebejjimus, pagrịstus tyrimų duomenimis, pateikè ir kitų šalių garsūs erozijos tyrèjai (Morgan, 2006).

\section{IŠVADOS}

1. Kalvų šlaituose augalų maisto medžiagų nuostoliai, prarasti su eroduotu dirvožemiu ir paviršiniu kritulių vandens nuotèkiu, priklausè nuo dirvožemio augalinès dangos, granuliometrinès sudèties ir šlaito polinkio. Didžiausi vidutiniai metiniai dirvožemio nuostoliai nustatyti lengvo priemolio $9-11^{\circ}$ šlaite (juodasis pūdymas), o paviršinio vandens nuotèkis - nuo vidutinio sunkumo priemolio $\left(7-9^{\circ}\right)$ ir sunkaus priemolio dirvožemio šlaitų $\left(7-8^{\circ}\right)$, apaugusių daugiametėmis žolèmis I-IV n. m.

2. Ilgalaikiai daugiakomponenčiai žolynai lengvo priemolio $9-11^{\circ}$ šlaite sumažino paviršinị vandens nuotèkị ir apsaugojo dirvožemị nuo erozijos.

3. Laikant juodąji pūdymą arba dirvožemị be augalinès dangos jautriausias nuardymui ir N, P, K maisto medžiagų netekčiai buvo lengvo priemolio 9-11 ${ }^{\circ}$ šlaito dirvožemis: per dvejus metus su dirvožemiu ir vandens nuotèkiu judriojo fosforo prarasta $34,39 \mathrm{~kg} \mathrm{ha}^{-1}$, azoto $-12,16 \mathrm{~kg} \mathrm{ha}^{-1}$, judriojo kalio - 32,86 $\mathrm{kg} \mathrm{ha}^{-1}$.

4. Šlaituose, apželdintuose augalais, judriojo kalio nuostoliai didesni su vandens nuotekiu, o judriojo fosforo ir mineralinio azoto - su prarastu dirvožemiu. Sunkesnio šlaito dirvožemio judriojo fosforo ir judriojo kalio nuostoliai mažesni.

5. Tarp paviršinio vandens nuotèkio ir mènesio krituliu kiekio nustatytas vidutinio stiprumo teigiamas ir patikimas koreliacinis ryšys: $r=0,61^{\star}$ 0,69* (2011 m.), $r=0,54-0,64^{*}$ (2012 m.). Dirvožemio nuostoliai kalvų šlaituose mažai priklausė nuo mènesio kritulių kiekio.

\section{PADE்KA}

Autoriai dèkoja Lietuvos žemès ūkio ministerijos Išteklių ir politikos departamento Agroaplinkosaugos ir ekologinio ūkininkavimo skyriaus darbuotojams už suteiktą finansinę paramą (sutartis MT/11-27). Taip pat dekkojame technikei Ritai Kinderytei ir kitiems darbuotojams, kruopščiai ir atsakingai atliekantiems skaičiavimus ir darbus stacionaruose.

Gauta 12121227

Priimta 12130424

\section{LITERATŪRA}

1. Asghari H. R., Cavagnaro T. R. 2011. Arbuscular mycorrhizas enhance plant interception of leached nutrients. Functional Plant Biology. Vol. 38. P. 219-226.

2. Bukantis A., Rimkus E. 1997. Lietuvos agroklimatinių išteklių kaita ir prognozès. Lietuvos klimato ir dirvožemio potencialo racionalaus naudojimo perspektyvos. Dotnuva-Akademija. P. 5-11.

3. Cerdan O., Govers G., Le Bissonnais Y., et al. 2010. Rates and spatial variations of soil erosion in Europe: A study based on erosion plot data. Geomorphology. Vol. 122. Issues (1-2). P. 167-177.

4. Erickson J. E., Cisar J. L., Snyder G. H., et al. 2005. Phosphorus and potassium leaching under contrasting residential landscape models established on sandy soil. Crop Science. Vol. 45. P. 546-552.

5. Jankauskas B., Jankauskienè G. 2003. Stacionariniai dirvožemio erozijos tyrimai Žemaičių aukštumoje: 1. Dirvožemis ir jo savybès. Žemdirbystė: mokslo darbai. T. 82. P. 3-19.

6. Joel A., Wesstrom I., Strock J., Messing I. 2012. Method for in situ measurements of water, sediment and phosphorous transport in the upper soil profile. Acta Agriculturae Scandinavica, Section $B$ - Soil \& Plant Science. Vol. 62. Suppl. 2. P. 252259.

7. London J. G. 2005. Nitrogen study fertilizes fears of pollution. Nature. Vol. 433. Issue 7028. P. 791.

8. Maetens W., Vanmaercke M., Poesen J., Jankauskas B., Jankauskienè G., Ionita I. 2012. 
Effects of land use on annual runoff and soil loss in Europe and the Mediterranean: A meta-analysis of plot data. Progress in Physical Geography. P. 1-55.

9. Morgan R. P. C. 2006. Soil Erosion \& Conservation (3th ed.). Blackvell Publishing. 304 p.

10. Staugaitis G., Mažvila J., Arbačiauskas J., Adomaitis T., Daunys A., Šumskis D., Ryliškienė E., Griškevičienè S., Antanaitis A. 2009. Lietuvos mineralinio azoto monitoringas ir jo tyrimai [žiūrèta 2012-12-05]. Prieiga per internetą: http://www. agrolab.lt/azotas.html

11. Tarakanovas P., Raudonius S. 2003. Agronominiu tyrimu duomenu statistine analizé taikant kompiuterines programas ANOVA, STAT, SPLIT-PLOT iš paketo SELEKCIJA ir IRRISTAT. Akademija. Kèdainių r. 57 p.

12. Vaitiekūnienė J. 2006. Integruotas upių baseinų nuotèkio ir taršos vertinimas: daktaro disertacija. Kaunas. 133 p.

13. Vanmaercke M., Poesen J., Maetens W., de Vente J., Verstraeten G. 2011. Sediment yield as a desertification risk indicator. Science of the Total Environment. Vol. 409. Issue 9. P. 1715-1725.

14. Warsta L. 2011. Modelling Water Flow and Soil Erosion in Clayey, Subsurface Drained Agricultural Fields. Aalto University publication series, Doctoral Dissertations 82/2011. Helsinki: Alto Print. 209 p.

\section{Irena Kinderienè, Gintaras Jarašiūnas,} Danutė Karčauskienė

\section{LOSS OF PLANT NUTRIENTS (N, P, K) WITH SOIL LOSS AND WATER RUNOFF FROM HILL SLOPES}

Sum mary

Field experiments were conducted in the Véžaičiai Branch of LAMMC in 2011-2012, on three Kaltinènai erosion stationaries, which are on $7-9^{\circ}, 9-11^{\circ}$ and $7-8^{\circ}$ slopes. Soils are classed as Albeluvisol Eutric Albeluvisols ( $A B e)$, medium and light eroded. On each slope of the stationary there are 10 plots equipped. In these years of experiments, perennial grasses, spring barley, potatoes, black fallow and long-term perennial grasses (sward) were grown.

It was obtained that soil losses of the water erosion, surface runoff and loss of nutrients mostly depended on the vegetation cover and soil texture. The slopes occupied with long-lived grasses, where strong sward is formed, are resistant to soil erosion. When the soil is without plants and fallowing, soil losses are substantially highest on a light loamy $9-11^{\circ}$ slope (229.34 $\mathrm{tha}^{-1}$ ) and a runoff is highest on medium and heavy loamy slopes.

The least water runoff (308.3-843.6 $\left.\mathrm{hl} \mathrm{ha}^{-1}\right)$ and minimum losses of dry soil $\left(0-1.56 \mathrm{t} \mathrm{ha}^{-1}\right)$ were determined on the light loamy $9-11^{\circ}$ slope occupied with long-lived multicomponent grasses. When the soil was black fallow or without plants, the light loam $9-11^{\circ}$ slope appeared to be most sensitive to erosion and losses of the N, P, K nutrients: during two years, $34.39 \mathrm{~kg} \mathrm{ha}^{-1}$ of available $\mathrm{P}, 12.16 \mathrm{~kg} \mathrm{ha}^{-1}$ of $\mathrm{N}$, $32.86 \mathrm{~kg} \mathrm{ha}^{-1}$ of available $\mathrm{K}$ were lost with the soil and runoff.

Correlative analysis provides mean relationship between the runoff and monthly precipitation $\left(r=0.61^{\star}-0.69^{\star}\right.$ (2011), $\left.r=0.54-0.64^{\star}(2012)\right)$. Low dependence between the soil loss and the monthly rainfall was defined.

Key words: slopes, erosion, soil losses, runoff, N, P, K, crop rotation, stacionaries 